\title{
ODIOUS DEBTS OR ODIOUS REGIMES?
}

\author{
PATRICK BOLTON* \\ DAVID SKEEL**
}

\section{I \\ INTRODUCTION}

Odious regimes have always been with us. That there is no silver-bullet solution that will prevent odious regimes from arising, or stymie them once they do, is evident from the plethora of responses employed by the international community once a regime's odiousness becomes clear. Trade sanctions may be used to try to choke off a malignant regime's access to weapons or other goods. In egregious cases, such as Milosevic's Serbian regime, the international community may take military action. Still another strategy, more talked about than implemented, is the one considered in this article: the use of the odious debt (or, we will argue, odious regime) doctrine to cut off, or at the least to complicate, an odious regime's access to outside funding.

Current odious debt doctrine-using the term "doctrine" loosely, since it has never been formally adopted by a court or international decisionmakerdates back to a 1927 treatise by a wandering Russian academic named Alexander Sack. ${ }^{1}$ Sack surveyed the handful of occasions on which a successor regime had repudiated the obligations of its predecessor as unenforceable, including the United States' refusal to honor obligations incurred by Cuba under Spanish rule and Costa Rica's repudiation of loans used by former dictator Federico Tinoco for his personal benefit. Based on this survey, Sack suggested that debt obligations are odious and therefore unenforceable if (1) they were incurred without the consent of the populace, (2) they did not benefit the populace, and (3) the lender knew or should have known about the absence of consent and benefit. ${ }^{2}$ Sack's tripartite definition quickly became the foundation of odious debt analysis, and it continues to be employed today, even

Copyright (C) 2007 by Patrick Bolton and David Skeel.

This Article is also available at http://www.law.duke.edu/journals/lcp.

* Barbara and David Zalaznick Professor of Business, Columbia University.

** S. Samuel Arsht Professor of Corporate Law, University of Pennsylvania. The authors are grateful to Anna Gelpern, Tom Ginsburg, Mitu Gulati, Melissa Jacoby, Howard Rosenthal, Bill BurkeWhite, and Mark Weisburd, and to participants at a faculty workshop at the University of North Carolina School of Law and at the Odious Debts \& State Corruption Conference at Duke Law School for helpful comments on earlier drafts.

1. See Alexander N. Sack, Les EfFets des Transformations des États sur leurs Dettes Publiques et Autres Obligations FinAnCiÈRes (Recueil Sirey 1927), available at http://www.odiousdebts.org/odiousdebts/publications/dettes_publiques.html (last visited Jan. 19, 2007).

2. Id. at 157 . 
by scholars who offer proposals quite different from the kinds of applications Sack himself seemed to have in mind.

The Sack definition contemplates a debt-by-debt approach to questionable borrowing. If a loan is used to benefit the population-to build a highway or water-treatment plant, for instance-the obligation would be fully enforceable, no matter how pernicious the borrower regime. Loans that a ruler used to oppress the people, on the other hand, or diverted for his own purposes, would be unenforceable if the lender knew or should have known the loan proceeds would be misused. This nuanced approach seems to address one of the most vexing dilemmas of punishing an odious regime: the risk that sanctions will harm a nation's innocent citizens more than the odious rulers. The Sack definition is designed to nullify odious obligations without discouraging lenders from funding projects that provide genuine benefits. As attractive as it sounds, however, the debt-by-debt approach has a debilitating weakness: money is fungible. A loan ostensibly incurred for beneficent purposes often may simply free up other money for misuse. The fungibility of money seriously limits the efficacy of debt-by-debt strategies for policing the borrowing of pernicious regimes.

The principal alternative to a debt-by-debt approach is to focus on the odiousness of the regime, rather than on the nature of a particular loan. The odiousness of the regime is not ignored altogether in the Sack definition. It is implicit, for instance, in the nonconsent requirement. A regime-centered approach would simply put the odiousness of the regime in the foreground. This strategy is the most promising way forward for the odious debt doctrine.

To make this case, an odious regime must first be defined. Perhaps because the Sack definition does not home in directly on the regime, prior scholars have not defined what should or should not count as an odious regime. More surprisingly, even the few commentators who do call for regime-centered perspectives elide the definitional question. ${ }^{3}$ This article attempts to fill the vacuum: a regime is odious if it engages in either systematic suppression or systematic looting. Odious regimes sometimes suppress a subgroup of the population, as with blacks in Apartheid South Africa and Jews in Nazi Germany, and they sometimes suppress the entire population, as with Idi Amin's Uganda. The suppression is often, but not always, accompanied by looting. Every odious regime is marked by one, the other, or both.

Once "odious regime" is defined, the question is how to make the definition operative. We propose that two existing institutions, the United Nations (U.N.) and the International Monetary Fund (IMF), share responsibility for identifying odious regimes. The U.N. is best positioned to determine whether a regime is

3. See, e.g., Seema Jayachandran, Michael Kremer \& Jonathan Shafter, Applying Odious Debts Doctrine While Preserving Legitimate Lending (2005) (unpublished manuscript, available at http://www.economics.harvard.edu/faculty/kremer/papers/Odious_Debt_Doctrine.pdf) [hereinafter Jayachandran et al., Legitimate Lending]; Seema Jayachandran \& Michael Kremer, Odious Debt, 96 AMER. ECON. REV. 82 (2006). 
engaging in systematic suppression, while the IMF would assess concerns about looting and other, similar, financial depredations. If the U.N. found evidence of systematic suppression, its declaration of odiousness, which could be made either while the regime was in place or after a new regime had emerged, would render obligations of the regime unenforceable. The IMF could police a regime's looting by imposing conditions on access to IMF assistance as well as by invalidating the regime's debt. After explaining the moral and economic case for intervention and surveying the strategies proposed by other commentators, we develop the definition of odious regime and offer our proposal for its implementation.

\section{WHY AN ODIOUS DEBT DOCTRINE IS DESIRABLE}

\section{A. The Moral Argument}

The moral case for an odious debt regime starts from the premise that some regimes are so repugnant that they should be actively condemned by the international community. The world cannot stand by silently as a regime murders its own people or loots the country's treasury while ordinary citizens starve. One crucial way to express international disapprobation is to discourage outside lenders from financing such a regime, particularly if the regime will use the financing to oppress its people or for the private enjoyment of the corrupt rulers themselves. Similarly, if an odious regime does manage to borrow money for malignant purposes, these loans should not be binding on a subsequent regime that replaces its odious predecessor. Such loans are tainted. As a matter of simple justice, they should not be treated as enforceable. This, in a nutshell, is the moral basis for the odious debt doctrine.

While the moral case is compelling, it is subject to two important complications. The first is that most odious regimes are not entirely odious all the time. Some loans, or portions of some loans, may be used for beneficial projects such as building bridges or roads, or expanding access to clean water. The principal beneficiary of these projects will often be the nation's innocent citizens. If these beneficial projects would not get done absent outside lending, an odious debt doctrine that cut off all lending to an odious regime could have dire humanitarian consequences. The dilemma is a familiar one-trade sanctions often pose the same risk-and it looms particularly large in considering how to implement an odious debt doctrine.

The second complication is determining what counts as odiousness for the purposes of odious debt analysis. The classical definition of odious debt obscures the issue somewhat by asking whether the populace benefited from or consented to a particular loan. Although this definition seems concerned with regimes that oppress their populaces or use the proceeds of loans as the leader's personal piggybank, it also can be construed more broadly. Some critics of lending by the industrialized world have done just this, suggesting that the 
obligations of every developing-world country saddled with excessive debts are odious. "The Third World should repudiate its debts," one commentator sweepingly advises. "Declaring debts odious will compel the lenders ... to seek redress by suing, pursuing and, where possible, seizing the booty of the unrepresentative Third World elites which borrowed so recklessly in the name of their people." ${ }^{4}$

In our view, this broad conception of odiousness confuses odious debt doctrine with a conceptually distinct concern-excessive debt, or "debt overhang." Debt overhang is a serious problem in the developing world; indeed, we have advocated the adoption of a formal sovereign-bankruptcy regime to address the problem of unsustainable debt. ${ }^{6}$ However, debt overhang is not the same thing as odious debt. Although some regimes that saddle their citizens with excessive debts are odious, many are not. It is critical to distinguish between the two. Otherwise, the doctrine would lose much of its moral forcesuggesting, for instance, that a truly odious regime like Idi Amin's Uganda is comparable to a nonodious regime that has incurred too much debt. From a moral perspective, then, odious debt doctrine should be limited to regimes that can genuinely be said to be odious.

\section{B. The Economic Argument}

The economic justification for an odious debt (or odious regime) doctrine starts with the intuition that, if loans to an odious regime are unenforceable, lenders may refuse to lend to the regime, thus preventing wasteful or harmful spending to some extent. In addition, as Jayachandran and Kremer argue, those who seek power mainly for their personal enrichment, or to oppress a minority, may struggle less intensively for power if they expect a financial straightjacket to be imposed on their regime. ${ }^{8}$ Finally, odious regimes are less likely to survive for prolonged periods if it is harder to sustain the regime financially. An effective odious debt doctrine thus can increase the welfare of the country (excluding, of course, the members of the regime) in at least three ways: (1) there will be a lower debt burden to service; (2) odious regimes, which reduce welfare, are less likely to emerge; and (3) should they emerge, they are less likely to survive for a long time.

4. Patricia Adams, Odious Debts: Loose Lending, Corruption, And the Third WORLD'S ENVIRONMENTAL LEGACY 194 (1991).

5. The classic analyses of the debt-overhang issue in sovereign finance are Paul Krugman, Financing vs. Forgiving a Debt Overhang, 29 J. DEV. ECON. 253 (1988); Jeffrey D. Sachs, The Debt Overhang of Developing Countries, in DEBT, STABILIZATION AND DEVELOPMENT 80-102 (Guillermo Calvo et al. eds., Basil Blackwell 1989).

6. Patrick Bolton \& David A. Skeel, Jr., Inside the Black Box: How Should a Sovereign Bankruptcy Regime Be Structured?, 53 EMORY L.J. 763 (2004).

7. Although discussion in the text focuses on moral concerns, a sweeping odious debt doctrine also could roil the sovereign-debt markets as lenders faced a significantly expanded risk of nonpayment.

8. Jayachandran \& Kremer, supra note 3. 
However, as Lancaster and Lipsey warned more than five decades ago, even a policy intervention that is clearly desirable in a first-best world may actually have perverse effects in a second-best world.' As a result, the economic argument for an odious debt doctrine is more complicated, and more ambiguous, than the moral argument. If the imposition of an odious debt doctrine induces odious regimes to misbehave even more, then it is less clear that the doctrine is justified on economic grounds. This point lies at the heart of a recent critique of odious debt doctrine by Albert Choi and Eric Posner..$^{10}$ They argue that an odious regime may become even more odious or destructive if it is shunned by international financers, and that the case for an odious regime policy therefore rests on a careful evaluation of the extent to which the regime's behavior is likely to worsen as a result of the policy. In their view, the evaluation is too complex in practice for any real world decisionmaker. While odious debt doctrine might be welfare-improving in a more perfect world, it is thus far more dubious under actual conditions. ${ }^{11}$ They also invoke considerations of realpolitik in dealing with dictators. No one wants to tolerate dictators, but allying with a dictatorial regime is sometimes a lesser evil.

Another obvious reason for caution under real world conditions is that the odious debt doctrine could increase the cost of capital for all sovereigns, good or bad. Because the doctrine would introduce a new risk for lenders-the possibility that their debts might be branded as odious-they would demand a higher risk premium. If the policy is confined to truly odious regimes, these costs would be limited; but a broader policy might have onerous effects on sovereign finance. Overall, these economic considerations suggest that odious debt doctrine can only be welfare-enhancing if it is carefully circumscribed.

\section{III}

\section{Practical ObSTACles AND Alternative APPROACHES}

The idea of an odious debt doctrine has been around for more than a century, and its standard contours have been settled for nearly as long. Despite its pedigree, Sacks's intuitively appealing, three-part definition of odious debts - no consent, no benefit, and awareness of these facts by the lender-has never been formally adopted. One obvious reason for the doctrine's precarious status is the difficulty of implementing it. "Upon hearing of the doctrine," as one advocate puts it, "most international lawyers are likely to believe that the doctrine could never be applied in practice. ${ }^{\text {"12 }}$ A robust odious debt doctrine

9. Richard G. Lipsey \& Kelvin Lancaster, The General Theory of Second Best, 24 REV. Econ. STUD. 11 (1956).

10. Albert H. Choi \& Eric A. Posner, A Critique of the Odious Debt Doctrine, 70 LAw \& CONTEMP. PROBS. 33 (Summer 2007).

11. "[T] $]$ he defenders of the doctrine have not made the empirical case," they argue, "that the net benefits are sufficiently high in the aggregate as to warrant routine application of loan sanctions to odious dictators." Id. at 51.

12. Jeff King, The Doctrine of Odious Debt Under International Law, in Advancing the Odious Debt Doctrine 48 (Ashfaq Khalfan ed., Mar. 11, 2003) (CISDL Working Paper), available at 
might also have damaging implications for the cost of borrowing by sovereigns as lenders stiffened the terms of their loans to protect themselves against the risk that those loans would later be deemed odious.

Spurred by the campaigns to cancel the debt of African nations and by the renegotiation of Iraq's Saddam Hussein-era debt, scholars have devised a variety of new proposals addressing these concerns. Under the most prominent of the proposals, an international decisionmaker would determine in advance whether a particular government is odious. Subsequent lenders would then be on notice that loans to the regime could be treated as odious and cancelled. Other scholars, questioning whether it is realistic to expect an international institution to brand existing regimes as corrupt, have suggested that domestic courts could use domestic-law tools such as agency law to invalidate obligations that fit the traditional Sackian definition. Still others call for a contractual approach, with lenders defining odious debt in their contracts with a sovereign debtor and determining through an ex post creditor vote whether some of the obligations are odious and should be cancelled.

The current debate has focused on the question of who the decisionmaker should be. Equally important is another question that is often assumed away: whether to focus on the odiousness of a given debt, or to focus more broadly on the odiousness of a given regime.

\section{A. Odious Debts Versus Odious Regimes}

With one prominent recent exception, both current commentators and their predecessors have advocated a debt-by-debt approach to resolving sovereigndebt issues. ${ }^{13}$ The principal alternative would be to focus on whether the regime in question, rather than particular debts, is odious. The choice between these approaches is the first major question in applying the odious debt doctrine.

In principle, the debt-by-debt approach has a great deal to recommend it. Even corrupt regimes sometimes undertake some projects that benefit their citizens-for instance, developing the nation's infrastructure by building roads or bridges. A blanket rule denying enforcement of loans made to an odious regime might interfere not only with corrupt borrowing, but also with these more beneficial loans. Lenders would either refuse to lend or would insist on onerous terms such as high interest rates or extremely short repayment periods. The beauty of a debt-by-debt approach is that it distinguishes between beneficial loans, which would be fully enforceable, and loans used to feed a dictator's Swiss bank account or to build a vanity palace, which would not.

http://www.odiousdebts.org/odiousdebts/publications/Advancing_the_Odious_Debt_Doctrine.pdf (updated and published in Jeff A. King, Odious Debt: The Terms of the Debate, 32 N.C. J. INT'L L. \& COM. REG. 605 (2007)).

13. See Jayachandran et al., Legitimate Lending, supra note 3. In their initial articles, Jayachandran, Kremer, and Shafter looked solely to the odiousness of the regime. More recently, they have developed a "due diligence" model that would enforce obligations owed to an odious regime if the lender conducted an adequate investigation before lending. 
Because it is tailored to the facts of each particular loan, the debt-by-debt approach counteracts the concern that the odious debt doctrine might chill even beneficial borrowing by an odious regime.

As attractive as it is in theory, a debt-by-debt strategy would be devilishly difficult to apply. One problem is that loans to corrupt rulers are often both good and bad, rather than entirely one or the other. In the 1970s, for instance, Ferdinand Marcos decided to undertake a massive nuclear energy project in the Philippines. ${ }^{14} \mathrm{He}$ seems to have selected the winning proposal based on the size of the bribe offered by the builder. The borrowing used to help finance the project was thus laced with corruption. Yet the apparent aim of the project-to improve access to electricity-arguably could have been beneficial to the nation's citizens. Many loans to corrupt rulers are likely to have this mixed quality, which could create intractable line-drawing problems for a debt-by-debt doctrine.

The other major application problem is related but even more intractable. Money is fungible. As a result, a loan that is made for ostensibly beneficial purposes may free up other money to be used corruptly, even if the loan is in fact used as promised. If lenders provide money for agricultural improvements, for instance, this may leave the ruler with more funds to buy weapons to oppress an ethnic minority or to fatten the ruler's bank account. The Abacha regime in Nigeria, to cite a particularly notorious illustration, used outside loans to fund the costs of running the country while stealing Nigeria's tax and oil revenues. ${ }^{15}$

The fungibility of money severely limits the potential effectiveness of the debt-by-debt approach to the odious debt doctrine. Even careful lender due diligence will not solve the problem, since lenders can determine only whether their funds are used as advertised, not whether the loan has freed up other money for misuse. Nor do corrupt regimes make it easy to follow the money. Quite to the contrary, the corruptness of the regime tends to be inversely correlated with the transparency of its finances. ${ }^{16}$

The fungibility problem does not necessarily mean that the traditional debtby-debt approach should be abandoned altogether. Indeed, it could play at least a limited role as a supplement to the approach we propose. But the limitations of the debt-by-debt strategy suggest that an alternative approach focusing less on particular debts and more on the nature of the regime is worth a closer look.

14. See, e.g., Joseph Hanlon, Defining Illegitimate Debt and Linking Its Cancellation to Economic Justice 43 (Norwegian Church Aid, June 2002), available at http://www.odiousdebts.org/odiousdebts/ publications/DefiningIllegtimateDebt.pdf; Joseph Hanlon, 'Illegitimate' Loans: Lenders, Not Borrowers, Are Responsible, 27 THIRD WORLD Q. 211, 215-16 (2006), available at http://www.oidido.org/IMG/pdf/IllegitimatedebtHanlon3WQJosephHanlon.pdf (final draft).

15. See, e.g., Noreena Hertz, The Debt Threat 181-82 (2004) (describing the plundering and characterizing the regimes of General Sani Abacha and General Ibrahim Babangida as "notoriously brazen and kleptocratic military regimes").

16. For an argument that the uses to which sovereigns put funds are not quite as difficult to trace as prior scholars (including us) have assumed, see Omri Ben-Shahar \& Mitu Gulati, Partially Odious Debts?, 70 LAW \& CONTEMP. ProBS. 47 (Autumn 2007). 


\section{B. The Choice of Decisionmaker}

The odious debt doctrine could be implemented by an international institution such as the U.N. or the IMF. ${ }^{17}$ These and related institutions figure prominently in the new odious debt literature. In addition, recent commentary has proposed several other potential decisionmakers, including the parties themselves and domestic courts.

\section{International Institutions}

The classical definition of odious debt seems to assume that an international decisionmaker will make its determination of odiousness after-the-fact-once the nation is under new management that questions the validity of previously incurred obligations. In principle, however, the determination could also be made in advance, by assessing the odiousness of a particular regime. The tradeoffs between these decision points are explored in more detail in Part V. Here the focus is on the decisionmakers themselves, beginning with international institutions.

The most likely candidates for an institutional decisionmaker are the U.N. and the IMF. (A third possibility is the International Court of Justice.) ${ }^{18}$ The most important benefit of these institutions, particularly as compared to the alternative decisionmakers discussed below, is that they are well-accustomed to addressing politically sensitive matters. The U.N. already determines whether atrocities rise to the level of genocide, for instance, which suggests that it should be the venue of choice for assessing the odiousness of a regime, particularly when the odiousness stems from the regime's mistreatment of its ethnic minorities or its people. Although the U.N. has been excruciatingly slow to label persistent violence as genocide, partly due to the influence of countries whose own track record of oppression is troubling, one might hope that it would intervene more readily in condemning a regime as odious since this would not immediately imply a risky, costly, and potentially controversial peace-keeping intervention. Rather, the main initial consequence of condemning a regime as "odious" would be to dry up the regime's sources of funding. Thus, an odious regime doctrine would have the treble benefit of (1) reducing the financial burden of countries that have been victims of odious regimes, (2) imposing a financial straightjacket on unsavory regimes, and (3) providing the U.N. with a

17. In practice, the application of principles similar to odious doctrine has usually been unilateral. Almost the only exception is the Tinoco arbitration decision made by former Chief Justice Taft. The Tinoco arbitration and other historical examples of debt repudiation are surveyed in King, supra note 12, at 21-30.

18. Khalfan focuses extensively on the potential role of the International Court of Justice, suggesting that the best strategy for proponents of odious debt doctrine might be to seek an advisory opinion from the ICJ. Ashfaq Khalfan, Sites and Strategic Legal Options for Addressing Illegitimate Debt, in Advancing the Odious Debt Doctrine, manuscript at 53 (Ashfaq Khalfan ed., Mar. 11, 2003) (CISDL Working Paper), available at http://www.odiousdebts.org/odiousdebts/publications/ Advancing_the_Odious_Debt_Doctrine.pdf. 
more readily utilizable, early-intervention stick than the "nuclear weapon" of a military peace-keeping mission.

In addition to political sensitivity, the other major issue is feasibility. Calls to create a new decisionmaking apparatus to arbitrate or resolve odious debt issues would be a tough sell, even in an era that was more enthusiastic about international institutions. In the current environment, there is simply no hope for such a proposal. ${ }^{19}$ But one can imagine an odious debt doctrine that made use of an existing international institution. The U.N. Security Council could begin identifying odious regimes today, if it wished, simply by adding this issue to its decisionmaking portfolio. Although a proposal to harness an existing institution's decisionmaking authority would still face resistance, it would likely face fewer obstacles than proposals requiring a new decisionmaker.

A final consideration is the scope of potential relief-that is, whether debt forgiveness would apply to bilateral debt, private lenders, or lending by the IMF and other multilaterals. In theory, one could devise a framework that dealt with all of these creditors. But a more realistic outcome is likely to be that bilateral and multilateral creditors would attempt to exclude themselves. In any case, the precise scope would vary, depending on the international institution involved and how its decisionmaking role were structured.

\section{Domestic Courts}

Prior to the 1970s, domestic courts played a relatively minor role in international finance because sovereign immunity insulated a sovereign from most litigation in domestic courts. Since then, many countries have enacted statutes explicitly excepting commercial obligations from sovereign-immunity protection, and a similar exception has become firmly established under customary international law. ${ }^{20}$ This retrenchment on sovereign immunity has made domestic courts an increasingly important venue for addressing sovereign-debt disputes, as evidenced by the spate of litigation over Argentina's debt obligations recently battled out in U.S. federal court. ${ }^{21}$ Several commentators have suggested that domestic litigation could be used to implement an odious debt doctrine. ${ }^{22}$

19. The possible need to add a new international institution has been a frequent practical objection to proposals to establish a sovereign-bankruptcy regime. In part to address these concerns, we ourselves have proposed that a sovereign bankruptcy regime could be implemented by existing domestic bankruptcy courts. See Bolton \& Skeel, supra note 6, at 812-18.

20. See, e.g., Charles N. Brower et al., The Foreign Sovereign Immunities Act of 1976 in Practice, in PROSPECTS FOR INTERNATIONAL LENDING AND RESCHEDULING, 73 AM. J. INT'L L. 200 (1979); LEE BuchHeit, How to Negotiate EuROCURRENCY LOAN AgREEMENTS 141-42 (2d. ed. 2004).

21. See, e.g., Marcus Miller \& Dania Thomas, Sovereign Debt Restructuring: The Judge, The Vultures and Creditor Rights (Warwick Econ. Research Paper, No. 757, 2006), available at http://www2.warwick.ac.uk/fac/soc/economics/research/papers/twerp_757.pdf.

22. The leading exemplars of this approach are Lee C. Buchheit, G. Mitu Gulati \& Robert B. Thompson, The Dilemma of Odious Debts, 56 DUKE L.J. 1201 (2007); Khalfan et al., Advancing the Odious Debt Doctrine (Ashfaq Khalfan ed., Mar. 11, 2003) (CISDL Working Paper), available at http://www.odiousdebts.org/odiousdebts/publications/Advancing_the_Odious_Debt_Doctrine.pdf. 
Under a litigation-based approach, a sovereign debtor would draw on domestic legal doctrine, either explicitly or by analogy, as a basis for invalidating some or all of the obligations incurred by an odious regime. Advocates of this approach point to basic agency law as the most promising doctrinal peg for judicial intervention. ${ }^{23}$ Under agency law, a principal is not responsible for obligations wrongfully incurred by his agent if the obligee knew or should have known the obligation violated the terms of the agency relationship. If the citizens of a country are viewed as the principal, the leaders as the agent, and creditors as the third party, this doctrinal framework maps neatly onto the traditional definition of odious debt. Debts incurred without consent by or benefit to a country's citizens, advocates argue, and to a creditor who is aware of these facts, should be deemed unenforceable. Courts might also rely on a variety of other doctrines, such as unjust enrichment, unclean hands, or assisting in a breach of trust.

A signal attraction of crafting an odious debt doctrine in the domestic courts is that all the pieces are already in place. There would be no need to create a new decisionmaking institution, and courts would apply doctrinal approaches with which they are already familiar. Moreover, the regime that sought to invalidate obligations of its corrupt predecessor might well be in a position to produce significant information about the circumstances under which the debts were incurred. Courts are also somewhat more insulated from political pressures than international institutions like the U.N. or IMF.

The translation from domestic agency law would not be quite as simple as the overview thus far suggests, however. Determining whether the sovereign's citizens had consented to or benefited from the loan proceeds would require the court to pass judgment on political issues that domestic courts are generally reluctant to delve into. The issues are far more delicate than with an ordinary commercial dispute. As a result, domestic courts might be quite reluctant to take the step from domestic agency law to the invalidation of odious debts.

Another practical limitation of the domestic litigation strategy is its limited reach. It could only be used only for lending by private creditors, since domestic courts would not have jurisdiction over a sovereign debtor's disputes with other sovereigns or with the IMF. ${ }^{24}$ Yet most of the debt owed by countries that are currently mentioned as possible victims of odious debt is owed to other sovereigns, the IMF, and other multilaterals. To give the most prominent recent example, the vast majority of Iraq's \$140-billion debt was owed to bilateral creditors.

In practice, the domestic-litigation strategy might be limited still more by the need to show that the lender knew or should have known the debt was wrongfully incurred. Whereas one can imagine such a showing when the lender

23. Buchheit et al., supra note 22, at 1237-44; Khalfan et al., supra note 22, at 3.

24. In theory, these disputes could be litigated in the International Court of Justice. Khalfan and others appear to view the ICJ as the most promising venue for formal adoption of odious debt doctrine. Khalfan et al., supra note 22. 
was a bank or other financial institution, it is more problematic with bonds, since individual bondholders are unlikely to have investigated their sovereign borrower nearly as carefully as bank lenders do. This suggests that domestic litigation is most promising with loans made by private banks and is probably limited to that context.

\section{Contract and Private Creditors}

Ever since collective-action clauses emerged as the strategy of choice for improving the architecture for restructuring sovereign debt, private contract has been the central theme of a great deal of international-finance scholarship. It was perhaps inevitable that this theme would be applied to the odious debt doctrine, and it has been. Under one proposed approach, the creditors of a sovereign debtor would include a definition of "odious debt" in their contracts with the debtor. If the obligations were later challenged as odious, the issue would be resolved by a creditor vote. The obligations would be disallowed if a majority or supermajority of creditors viewed them as odious. ${ }^{25}$

The contractual approach offers several important benefits as a strategy for implementing the odious debt doctrine. First, private creditors might have different or better information about the financial condition of a given regime than public decisionmakers. Private creditors might also be less influenced by overtly political factors in their decisionmaking, since their principal objectives are financial rather than political. Finally, the contractual voting solution is arguably more market-based than the other alternatives, a quality that is attractive both because it does not require the creation of a new decisionmaking institution and because it nicely resonates with the ethos of our particular historical moment.

Offsetting these benefits are several obvious limitations. It is not at all clear, for instance, how private creditors would conduct the investigation necessary to determine whether an obligation is odious, particularly with respect to lending done not by them but by other creditors. ${ }^{26}$ Moreover, the creditors would be required to investigate the behavior of other lenders, some of whom may have lent at very different times, to determine whether the other lenders were aware that their funds were being improperly used. Finally, to the extent the odious debt standard incorporated political as well as financial factors, as does every existing definition of odious debt, creditors would have no particular information advantage.

In addition to these information issues, there also is a risk that creditors would base their vote on factors other than their perception of the odiousness of the debts in question. Creditor voting tends to be based on economic considerations rather than moral ones. As a result, the creditor vote might be

25. Adam Feibelman, Contract, Priority, and Odious Debt, 85 N.C. L. REV. 727, 750 (2007).

26. Feibelman suggests that the tools of forensic accounting are adequate for the task of assessing the odiousness of a regime's debts. Id. at 761-63. We are less optimistic about the capacity of forensic accounting when the debtor is a sovereign nation rather than a private corporation. 
influenced more by the question of whether restructuring would increase the likelihood of repayment than by the odiousness of the debts.

To put the same point in slightly different terms, creditors' decisionmaking is best when creditors are pursuing their own financial best interests, making decisions that maximize their expected return. But odious debt doctrine has little to do with maximizing the creditors' return in any direct way. ${ }^{27} \mathrm{~A}$ creditor would be voting on the treatment not of itself, but of another class of creditors, and would ostensibly be casting this vote without reference to the creditor's own financial best interests. This is not the kind of decisionmaking that creditors are likely to do especially well.

As with domestic courts, contractual solutions are generally limited to private-debt obligations. They would not address odious debts owed to other sovereigns or to the IMF.

\section{IV}

\section{ODIOUS REGIMES: A DEFINITION}

As rich and extensive as the literature is, odious debt scholars have yet to develop a definition of what constitutes an odious regime. Nearly any international lawyer can quickly rattle off Sack's three-pronged definition for odious debts. But one searches in vain for either a similarly well-accepted, or at least well-developed, definition of an odious regime. ${ }^{28}$ In part, the vacuum seems to reflect a conclusion that the odiousness of regimes is too contentious an issue to get into. "Someone," to borrow the words of several leading scholars, would be required to "assume the task of painting a scarlet ' $\mathrm{O}$ ' on a great many regimes around the world" if such a definition were developed and applied. ${ }^{29}$ The perceived difficulty of devising a workable definition may also be a factor.

Whereas sidestepping the question of what constitutes an odious regimeleaving it to an international decisionmaker without constraining the decisionmaker's mission-may seem a wise exercise of restraint, doing so has two pitfalls. First is the obvious danger of inviting a descent into ethical relativism. If we assume that the odiousness of a regime is mainly in the eyes of the beholder, and hesitate to single out any regime as odious, we may be forced to resign ourselves to the existence of the most dreadful regimes. Although perceptions of odiousness have evolved to some extent over time, some regimes

27. It is possible that creditors who lend non-odiously would view odious lending as compromising their own prospects for repayment, see id. at 770, but the effect seems likely to be attenuated and indirect at best.

28. It is striking in this regard, as noted earlier, that Jayachandran, Kremer, and Shafter, who are the principal proponents of a regime-based perspective, have explicitly sidestepped the question of how to define an odious regime. See Jayachandran et al., Legitimate Lending, supra note 3, at 18-19 (criticizing a proposal made by Jeff King and proposing that an international organization "be enlisted or designed to declare ex ante that specific governments are odious-debt prone").

29. Buchheit et al., supra note 22, at 1203. 
are repugnant to the overwhelming majority of people; these regimes ought to be condemned by the international community as odious. The second pitfall is to be overinclusive and to brand, say, any nondemocratic regime as odious. The discussion that follows outlines a simple, plausible definition of odious regime that is designed to avoid each of these problems.

To more fully convey both the importance and the potential stumbling blocks of the project, it may be useful to begin by highlighting two key impediments. The first, already alluded to, is widely divergent intuitions as to the odiousness of particular regimes. The U.S. government would no doubt be quick to label the Chavez government in Venezuela and Castro's Cuba as odious. The governments of other countries, on the other hand, including some in Europe, might not be so sure. Another difficulty is that the most obvious starting point - whether the country is a dictatorship or a democracy-turns out to be much less useful than one might wish. Venezuela and Peru are both democracies, but some might be inclined to characterize each as odious. On the other hand, although Singapore is a dictatorship, most would be hesitant to question its borrowing as potentially odious.

Perhaps the best way to move beyond the initial impasse is to identify the qualities of regimes that are undeniably odious. Most commentators would agree that Nazi Germany, Cambodia's Khmer Rouge, South Africa's Apartheid, Zaire's Mobutu, Chile's Pinochet, Rwanda's Hutu government and Interahamwe and Impuzamugambi militia groups, Serbia's Nationalist Government of Slobodan Milosevic, Uganda's Idi Amin, Zimbabwe's Robert Mugabe, Liberia's Charles Taylor, or North Korea's regimes of Kim Il-Sung and Kim Jong-Il were or are odious. What do these regimes have in common? One common theme is that nearly all, by the standards of their time, used extreme oppression and brutality to suppress a particular ethnic group or the population at large. Some of the regimes are or were also characterized by systematic looting of their country's wealth by its leaders. Thus, an odious regime is, first, one that has an overt policy of terror and oppression, and denies the basic well-being, freedoms, and human rights of its people. And, second, it is a regime that is engaged in a policy of systematic looting for the benefit of the ruling elite. A regime that has either or both of these attributes is, in our view, an odious regime.

Systematic suppression, the first of the two alternative indicia of odiousness, is the broader of the two and requires some elaboration. A key component of systematic suppression is the absence of voice..$^{30}$ Given that dictatorship removes the most obvious channel for citizen voice - the right to choose their leaders-it is not surprising that many of the patently odious regimes-Cambodia, Uganda, Nazi Germany-have been dictatorial. But citizens do not always lose their voice in a dictatorship or other autocratic government; they sometimes have

30. We are piggybacking on Hirshman's classic analysis of exit and voice here. ALBERT O. HiRSCHMAN, EXIT, VOICE \& LOYALTY (Harvard Univ. Press 1970). 
alternative mechanisms for influencing their leadership. Civil-society organizations can serve as a check on a dictatorial government if they are allowed to speak freely, as can the media if it is not controlled or censored by the government. For instance, although Russians had little or no direct voice in Tsarist Russia, "a freedom-loving Russian," as the novelist Vladimir Nabokov recalled in his memoir, "had had incomparably more means of expressing himself, and used to run incomparably less risk in doing so, than under Lenin" because of "a vigorous public opinion that held despots at bay" and because the newsstands carried "widely read periodicals of all shades of liberal political thought." ${ }^{31}$ A nondemocratic regime also may be widely tolerated-if not accepted-by the population if it broadly rules in the interests of its people; preserves basic human rights, if not the rights to self-expression; and if it is seen as keeping a lid on potential costly conflicts, as in Tito's Yugoslavia.

Democracy has precisely the opposite relationship to voice. Robust democracy is the classic example of effective voice. But the presence of a democratic form of government, and even regular elections, does not by itself assure that citizens have meaningful voice. "Even elections can be deeply defective," as Amartya Sen has forcefully argued, "if they occur without the different sides getting an adequate opportunity to present their respective cases, or without the electorate enjoying the freedom to obtain news and to consider the views of the competing protagonists." ${ }^{32}$ Under Mugabe, Zimbabwe ostensibly has held elections, but ordinary citizens have had no real voice either in the elections or in the nation's affairs. So, too, when elections were held in the former Soviet Block countries, or in Chile under Pinochet.

The key question, then, is not so much whether the government is a dictatorship, a democracy, or something in between. It is whether ordinary citizens, those who are governed, are themselves in a position to influence their rulers or are able to protect their basic rights. If they are not (or a large, identifiable subset is not), the citizens do not have voice.

In a regime that engages in systematic suppression, the absence of voice invariably is accompanied by the brutal denial of basic rights. Citizens or a disfavored class may be systematically persecuted, have their property seized and their most basic freedoms denied; they may be murdered or jailed at the whim of the government; they may be prevented from leaving the country. These deprivations stifle potential dissent, completing the pattern of suppression.

The other indication of an odious regime is systematic plundering of a country's riches for the benefit of the ruling elite. The plundering is often facilitated by an absence of transparency with respect to the government's operations, its revenues, and how they are allocated. Nigeria's Abacha regime,

31. Vladimir Nabokov, Speak, Memory 264 (G.P. Putnam's Sons 1966) (1951).

32. Amartya Sen, Democracy as a Universal Value, 10 J. DEMOCRACY 3, 9 (1999), available at http://muse.jhu.edu/demo/jod/10.3sen.html. 
as noted earlier, plundered much of Nigeria's tax and oil revenues. Several of the regimes identified as clearly odious in this section engaged in similarly pervasive plundering. In our view, a regime that exhibits this behavior is an odious regime.

A regime that is characterized either by systematic suppression or by systematic plundering is odious. Although many odious regimes will meet both criteria, some will not. South Africa's Apartheid regime did not systematically plunder, for instance, but it systematically suppressed the black population and would decidedly qualify as odious. Short of an international, peace-keeping intervention to topple such regimes, these regimes should, to the extent possible, be denied access to international financial markets, and their citizens should not have to bear the financial burden of repaying the debts incurred by the regimes.

To further develop this definition, it is useful to apply it to several more current and historical regimes. One regime often mentioned as evidence of the difficulty of devising a workable definition of odiousness is America in the early nineteenth century, before slavery was abolished. ${ }^{33}$ In important respects, antebellum America fits the definition of an odious regime as systematically oppressive: African Americans had no vote and thus did not appear to have a meaningful voice, they were denied basic human rights, and the lack of voice and denial of rights were part of a pattern of systematic suppression. Although this is as close a case as we can imagine, nineteenth century America would likely not have ultimately been defined as odious. Although blacks were denied both the vote and basic human rights, antebellum America did not particularly stand out as odious compared with the rest of the world. Had an odious regime policy been in place at the time, it is doubtful that there would have been widespread consensus for identifying America as odious. This historical episode serves as a useful reminder that what is considered as odious has changed and changes over time. We are hopeful that this change is permanent with respect to slavery and that Martin Luther King rightly proclaimed that "the arc of the moral universe is long, but it bends toward justice." ${ }^{34}$

Turn to a more recent and simpler case. Many Americans view Hugo Chavez's Venezuela as an odious regime, given the demagogic quality of Chavez's rhetoric and his aggressive anti-Americanism. But Venezuela does not meet either criterion for an odious regime. First, although its behavior has been worrisome at times, the Chavez regime does not appear to have systemically suppressed the populace. Venezuelan citizens have meaningful voice, as reflected in the nation's recent, relatively fair election after a contested

33. See generally Jayachandran et al., Legitimate Lending, supra note 3, at 18 (suggesting that the American South during the Jim Crow era could be viewed as odious under some definitions of odiousness).

34. See, e.g., TAYlor BRANCH, PARTing the Waters: America IN THE King YeARs 1954-63 197 n.* (Simon \& Schuster Inc. 1988) (describing this as a favorite King line, quoted from abolitionist pastor Theodore Parker). 
campaign. Similarly, although Chavez has been accused of stifling dissent, any abuses do not appear to rise to the level of widespread denial of basic rights. Second, the Chavez regime has not systematically plundered Venezuela's finances.

One current regime that does qualify as odious, as reflected in its inclusion on the list of odious regimes at the outset of the discussion, is Zimbabwe under Robert Mugabe. As Mugabe has consolidated power, he has eliminated meaningful voice for any of the nation's citizens. There are no genuine elections or free media, and civic-society organizations have been almost entirely stifled. He also has denied basic rights by jailing potential dissenters and engaging in a campaign of expropriation of white landowners, among others. The overall pattern is one of systematic suppression that can only be described as odious.

Finally, as an illustration of the potential upside of international action, consider the case of Muammar al-Gaddafi's Libya. Although it would not qualify as odious under the systematic suppression standard, and terrorism is in a sense a separate category of international malevolence ${ }^{35}$ Libya provides a clear illustration of the effects that international sanctions can have on an outlaw regime. With the regime's overt support of international terrorist organizations and following the bombing of Pan Am Flight 103, the international community imposed economic sanctions on Libya that went beyond even what might be envisioned under an odious regime policy. Over time these sanctions have proved sufficiently costly to cause Libya to sharply change its policy in 2003 by accepting responsibility for the bombing and by agreeing to pay compensation to the families of the victims.

The analysis thus far provides only a basic framework for assessing whether a regime is odious. The discussion of implementation that follows will further develop that framework.

\section{REMEDIES AND THE ROLE OF THE U.N. AND IMF AS DECISIONMAKERS}

How would an odious regime policy be operationalized? What are the contours of the policy, its potential pitfalls and limits? The basic elements to implement an odious regime policy are already in place. Expert decisionmaking bodies already exist and, as long as one confines the implementation of the policy to these bodies, only relatively straightforward extensions of existing policy are required to put an odious regime policy into action.

35. Most contemporary terrorism is committed by nonstate terrorist organizations. Libya's regimebased terrorism was thus somewhat exceptional. Interestingly, international and domestic decisionmakers have implemented sanctions against terrorism that are even stronger than the remedies against odious regimes advocated in this article. See, e.g., Uniting and Strengthening America by Providing Appropriate Tools Required to Intercept and Obstruct Terrorism Act (USA Patriot Act), Pub. L. No. 107-56, 115 Stat. 272 (codified in scattered sections of the USC) (U.S. legislation providing, among other things, new provisions criminalizing involvement in money laundering); S.C. Res. 1373, U.N. Doc. S/RES/1373 (Sept. 28, 2001) (requiring criminalization of terrorism and denial of financial support or safe haven for terrorists). 
Rather than isolate and anoint a single decisionmaker, we envision a role for both the U.N. Security Council and the IMF's executive board in enforcing an odious regime policy. The U.N. is best placed to make the political judgment and to elicit an international consensus on whether a regime systematically denies voice to its people and is engaged in unrelenting suppression. The IMF, on the other hand, is better placed through its Article IV surveillance mission to determine whether a regime is engaged in systematic plundering. When an odious regime is systematically engaged in suppression as well as in plundering, as has often been the case in the past, both international institutions would have authority to declare the regime odious. ${ }^{36}$

\section{A. The Timing Question: When Should the Decision be Made?}

Before exploring the roles we envision for the U.N. and IMF in more detail, it may be useful to briefly address the question of timing. Should the determination of odiousness be made ex ante, while the regime is in place and before debts are incurred, or after the regime has been removed?

The timing of the condemnation of a regime should be flexible, determined both by the time when sufficient evidence of malfeasance has emerged and by political feasibility. There are, of course, benefits to making the determination of a regime's odiousness as early as possible, while the regime is still in power. An early declaration of a malfeasant regime as odious can allow a financial straightjacket to be applied immediately on the regime. In extreme cases in which a financial crisis is precipitated by the pronouncement, the regime might even be toppled, or at least be quickly induced to change its behavior. But, even if an early declaration is not possible and the regime or its bad policies have disappeared before a declaration has been made, an ex post declaration still would provide important benefits.

First, as long as debts incurred by the odious regime remain outstanding, these debts could be annulled, providing financial relief to the later regimes. There is also an ex ante benefit in permitting such an ex post intervention: the threat of subsequent annulment would discipline potential lenders, encouraging them not to lend too recklessly to odious regimes. This disciplining effect has a downside as well, however. An almost inevitable cost of an odious regime policy is to increase the risk of lending to sovereigns, and therefore the cost of borrowing for all sovereigns. This is why it is important to delineate clearly the contours of the intervention and the standards of proof. Pursuing a policy that allows for maximum flexibility as to the timing of its implementation, but

36. In those situations we envisage that the two institutions would be engaged in healthy competition to be the first to declare the regime as odious. In the domestic sphere, the jurisdictions of the Securities and Exchange Commission and the Commodity Futures Trading Commission overlap in somewhat analogous respects. For an analysis of some of the benefits of competition between regulators, see, for example, John C. Coffee, Competition Versus Consolidation: The Significance of Organizational Structure in Financial and Securities Regulation, 50 BUS. LAWYER 447, 474 (1995); see also John C. Coffee, Law and the Market: The Impact of Enforcement (Columbia Law \& Econ. Working Paper No. 301, Mar. 7, 2007), available at http://ssrn.com/abstract=967482. 
requires a high standard of proof and targets only regimes engaging in radical malfeasance, can significantly limit the additional risk created by an odious regime policy. It would then be clear to lenders that there is a negligible odiousness-risk for most sovereigns. At the same time, to the extent that sovereign-debt markets are good aggregators of information concerning the potential odiousness of a regime, a malodorous regime would be quickly penalized with a higher cost of borrowing, even if the actual official declaration of odiousness were made at a substantially later date, when incontrovertible evidence of the regime's malfeasance became available.

Even if the international decisionmaker rarely labeled a regime odious until after most of its debt obligations had expired, as might often be the case due to institutional inertia, each new condemnation would clarify odious regime policy for the purpose of future implementation against future regimes and would impose at the very least a reputation cost on the members of the regime. Identifying a regime as odious also could facilitate lawsuits seeking restitution of stolen funds or property by both the new regime and by victims of the odious regime. Thus, for example, one could envision a remedy whereby international banks would be required to lift bank secrecy or return funds of members of the odious regime to the new representative government of the country from which they have been looted.

\section{B. The U.N. Security Council as Arbiter of Systematic Suppression}

The U.N. Security Council is empowered to impose sanctions under Chapter VII of its charter as an alternative and a supplement to armed peace-keeping interventions. ${ }^{37}$ Under this provision, the Security Council already has the authority to implement an odious regime policy. Indeed, the U.N. and some of its member countries have recently introduced targeted financial sanctions, ranging from freezing financial assets to barring and even criminalizing financial transactions of targeted organizations and individuals. ${ }^{38}$ There is thus a small step from implementing these types of sanctions to implementing an odious regime policy. The only innovation would be the added reach of denying enforcement of debt repayments for any debts incurred by an odious regime. Even here, the policy could be implemented flexibly, by targeting only the debts that have been incurred at a time when clear evidence confirmed the regime's odious policies. ${ }^{39}$

37. U.N. Charter ch. VII.

38. The U.N. Security Council does not have the authority under Chapter VII to directly alter the domestic laws of the U.N.'s member nations. Rather, it instructs the members to adjust their laws. The effectiveness of its decisions thus depends on the members' compliance. The relative haste with which the leading nations have implemented recent terrorism sanctions gives some basis for optimism that most or all of the key countries would enact the sanctions outlined in the text. See supra note 35 (citing U.S. and international antiterrorism measures). See also United Nations, U.N. Security Council Counter-Terrorism website, http://www.un.org/sc/ctc/ (last visited May 29, 2007) (describing the U.N.'s antiterrorism measures).

39. The U.N. Security Council resolution shielding Iraq's oil and gas assets from debt collection actions by private creditors provides an early, albeit limited, example of the type of intervention the 
An important benefit of extending the U.N.'s arsenal of possible sanctions to include an odious regime declaration deemed sufficient to cancel the regime's debts is that this new sanction would significantly strengthen existing financial sanctions, which are difficult to enforce and which have limited reach. Unlike financial and trade sanctions as they are currently implemented, the odious regime policy proposed in this section would require very little monitoring and would to a large extent be self-implementing, since later regimes of the borrowing country would have every incentive to refuse to pay the debts incurred by the odious predecessor. Sovereign-debt lenders, of course, understand this and would stop lending when the risk that a regime would be declared odious substantially increased. As a result, an odious regime policy could have much more bite than the current sanctions the U.N. imposes and would provide an important substitute-early warning intervention-or even a complement to its bloodier and riskier military peace-keeping interventions. This is particularly so for nefarious nations that depend on the international financial markets for funds. If the regime has taken hold in a wealthy country with large export revenues, on the other hand, as is the case in Saudi Arabia, the policy obviously would have little effect.

There are inevitable concerns with a U.N.-overseen odious regime policy, and they need to be considered in some detail. The first issue is the U.N. itself. Even apart from concerns about internal management at the U.N., the U.N. Security Council might fail to condemn odious regimes that happen to be on friendly terms with a majority of countries or who are allies of a permanent member on the Security Council. The U.N.'s reluctance to attach the label of genocide to widespread persecution in Sudan and elsewhere is an illustration of this problem. Although the risk of foot-dragging must be acknowledged, in those instances where the Security Council did act, its pronouncement would better reflect international mores than that of another international decisionmaker. Moreover, the concern that the Security Council would be too slow to act - that there would be too many false negatives, to put the point in more colloquial terms -is partially offset by two countervailing considerations: first, even if the Security Council only rarely condemned odious regimes, even these rare condemnations would be an important step forward. So long as there was some prospect of condemnation, even a limited one, the doctrine could have beneficial effects. Second, even if the Security Council almost never condemned existing regimes, it might be more willing to condemn regimes after they lost power. Although in an ideal world the determination would be made sooner rather than later, an after-the-fact determination would provide many of the same benefits, as discussed earlier.

A second set of concerns relate to the scope of the proposal: which debts would be invalidated by the determination that a regime is odious? If all of a 
country's debt were canceled, regardless of when and by which regime it had been incurred, the government succeeding an odious regime might default too liberally on the country's outstanding debts. This risk suggests an obvious limitation on the scope of debt cancellation: only the debts incurred while the regime qualified as odious should be annulled. Canceling only the debts incurred during the period of odiousness would dampen any incentive sovereigns might have to manipulate the doctrine (by, for instance, tolerating a descent into odiousness due to the promise of complete debt cancellation).$^{40}$

A more difficult question is how to treat debts incurred by the odious regime in the process of rolling over past debts it has inherited from a nonodious predecessor. Should the originally legitimate debts be annulled? Yes: all the debts incurred by the odious regime should, in principle, be voided, whether these debts are incurred to service older debts or not, as this would allow for the strongest financial sanction on the regime. ${ }^{41}$ In the worst scenario for the old debts, the odious regime would then simply not be able to roll over the past debts and would be forced to default. In that case, the old-debt holders would continue to have a claim on the country, which they could enforce in the future against the governments succeeding the odious regime. Thus, the succeeding government would not escape the country's debt obligations incurred prior to the advent of the odious regime.

Still another conundrum is dealing with private debts incurred by, say, banks in the borrowing country, which are then channeled through the banking system to the odious regime. Should these also be annulled? One reasonable response is that even though the loans made by the banks to the odious regime should reasonably be considered odious debts, there are no other grounds for annulling the loans incurred by the banks themselves (unless, of course, clear evidence indicated that the banks were closely connected to the regime at the time the banks incurred their debts).

But a major difficulty with this response is that the banks may have been coerced into lending to the regime. They may have borrowed in order to then avoid punishment by lending to the regime. In that case, it is difficult to envisage a solution that would not result in the consolidation of the banks' debts into the debts of the regime. Should this consolidation be too farreaching, depriving some citizens of repayment on a loan they were coerced into making to the regime, these citizens would still have legal recourse and be able to seek repayment as victims of the odious regime.

In addition to these questions of scope, a third concern is that the implementation of an odious regime policy could result in the permanent

40. Ideally, a successor regime would also be permitted to retrieve any payments that had already been made on debt incurred by an odious regime, much as a debtor can retrieve "preferences" under U.S. domestic bankruptcy law. See 11 U.S.C. $\$ 547$ (b) (2000). Trying to implement such a rule would introduce substantial administrative complexities, however, which suggests that cancellation of unpaid debts alone is a more plausible sanction.

41. By similar reasoning, debts incurred by an odious regime that were subsequently reaffirmed by a non-odious successor regime should be enforceable. 
exclusion of a few pariah states from the international community. ${ }^{42}$ It is thus important to spell out a procedure and conditions under which a regime branded as odious could reverse this international condemnation. One straightforward scenario is when the odious regime has been displaced by a more reasonable government that has openly forsaken the worst malfeasance of the previous regime. Such a change in government should by itself trigger the removal of the condemnation. But the policy should also permit a lifting of the condemnation and other sanctions following a change of the regime's behavior, as for example in the recent case of Muammar al-Gaddafi's Libya. Libya eventually agreed to renounce support of international terrorist organizations, give up its nuclear arms program, and comply with the demands of the international community to make reparations for the victims of the Lockerbie terrorist attack as well as to bring the main perpetrators to justice.

The final concern with the implementation of an odious regime policy, or for that matter with any sanctions against an odious regime, is the humanitarian concern that the main victims of the sanctions may be the populations oppressed by odious regimes. In response to these concerns, the U.N. would always have the flexibility of postponing condemnation of a regime to a time when the regime has faded away and when humanitarian aid is easily available, or when there are no humanitarian concerns.

However, the benefits of this flexibility may be limited if debt markets anticipate the eventual condemnation of the regime. The prospect of eventual repudiation could prevent a regime from raising funds of any kind through sovereign-debt markets. For example, a plausible scenario in the case of, say, Mugabe's Zimbabwe could be a major collapse in food crops resulting in a widespread famine. The famine would be averted if the government could borrow in international markets to pay for food imports and thus ward off widespread starvation. But under an odious regime policy, the government would not be able to borrow.

The odious regime policy must be adjusted to allow access to credit even for an odious regime under these circumstances. A humanitarian escape clause to the odious regime policy would do this: it would permit the enforcement of debts by an odious regime in extreme circumstances to avoid a humanitarian crisis. Alternatively, the international community could authorize and guarantee a loans-for-food program similar to (but hopefully more effectively monitored than) the Oil-for-Food program under Saddam Hussein in Iraq. In other words, the escape clause would transform the odious regime policy in exceptional circumstances into a non-odious, humanitarian-debt policy.

42. This is a familiar concern with shaming sanctions in a wide variety of contexts. See, e.g., JOHN BRAITHWAITE, CRIME, SHAME, AND REINTEGRATION (1989) (discussing the danger that shaming will create or reinforce deviant subcultures). 


\section{Taking Aim at Plundering: The International Monetary Fund's Executive Board}

For policing systematic plundering, the most logical decisionmaker would be either the World Bank or the IMF, the two institutions established at the end of World War II to promote development and financial stability. In the last few years, the World Bank has placed a strong emphasis on identifying and attempting to counteract corruption in developing countries. Because systematic plundering is a particularly egregious form of corruption, the expertise that has been developed within the World Bank could make it an effective arbiter of this form of odious regime. On balance, however, the IMF appears to be even better positioned to play this role, due to its expertise and to the sanctions it has or could relatively easily put in place.

Under its Article IV surveillance mission, the IMF already conducts regular, extensive financial reviews of each of its members. ${ }^{43}$ Not only will the review often uncover evidence of plundering, but the report that accompanies it could lay the groundwork for IMF action. If a regime were found to be odious, the IMF could impose two separate sanctions. First, the Fund would deny access to IMF liquidity assistance in a crisis. Second, it would declare any debts incurred by the odious regime unenforceable. The IMF board would decide whether to condemn a regime as odious in the same way the board decides on whether to grant a program to a member country facing a temporary liquidity crisis.

Given the severity of the sanctions, the decision to condemn a regime as odious should be taken only in extreme cases for which there is widespread agreement. But it is equally important to avoid protecting odious regimes that happen to be allies of major voting members, especially if these members hold disproportionate voting shares. Thus, the implementation of an odious regime policy by the IMF would most likely be made easier following the implementation of governance reforms currently being debated, which aim to allocate voting shares of member countries in proportion to the member country's share in the world population or in world Gross Domestic Product. ${ }^{44}$

The idea that the IMF should put in place ex ante conditions for access to IMF financial support is neither novel nor particularly radical. It was already featured in the Contingent Credit Line (CCL) facility introduced by the IMF in 1999 but later withdrawn in $2003 .^{45}$ Ex ante conditions were also a central recommendation of the Meltzer Report (2000) on reforming international financial institutions. The Report recommended in particular that the IMF

43. For an overview of the IMF's Article IV surveillance obligations, see, for example, LEGAL DEPARTMENT, IMF, ARTICLE IV OF THE FUND'S ARTICLES OF AGREEMENT: AN OVERVIEW OF THE LEGAL FRAMEWORK (June 28, 2006), available at http://www.internationalmonetaryfund.com/ external/np/pp/eng/2006/062806.pdf.

44. IMF, "REFORM OF IMF QUOTAS AND VOICE: RESPONDING TO CHANGES IN THE GLOBAL ECONOMY" (Apr. 2007), available at http://www.imf.org/external/np/exr/ib/2007/041307.pdf.

45. See Policy Development and Review Department, IMF, "Review of Contingent CREDIT LiNES (Feb. 11, 2003),” available at http://www.imf.org/external/np/pdr/fac/2003/021103.pdf. 
make sound public-finance policies a prerequisite for access to IMF bailouts in a crisis. If the Report's recommendations were followed, the IMF would only offer crisis assistance to countries that had acceptable fiscal standards in place. ${ }^{46}$ In addition, a number of leading scholars have pointed to the potential benefits of ex ante conditionality in helping reduce problems of moral hazard in lending. ${ }^{47}$

Despite the potentially important benefits to be obtained from the introduction of such ex ante access conditions, none of the proposed policies has actually been implemented. One important reason is the concern among many policymakers that, although ex ante conditionality is straightforward in theory, it is not really practical in a world in which there is substantial heterogeneity among member countries as well as disagreement among economists as to what conditions member countries must meet. The European Union's Maastricht criteria are often viewed as a prime illustration of this problem. Given how mightily the relatively homogenous European-monetaryunion member countries struggled to achieve consensus on basic criteria for fiscal restraint, the reasoning goes, there is little hope that the far more diverse IMF member countries could ever agree on common principles. Critics also note that when the Maastricht criteria have been put to the test-in particular in Germany, France, or Italy-they have been broken without major consequences for these countries.

In addition, critics contend that ex ante conditions could precipitate unwanted financial crises in the few member countries that would not qualify. If investors shunned countries the IMF labeled as noncomplying, the ex ante conditionality policy could itself trigger a crisis. What is worse, the IMF would be prevented by its ex ante conditionality policy from intervening in the crisis its policy had partly produced. ${ }^{48}$

Although these concerns are important obstacles to a policy of ex ante conditionality on the access to IMF liquidity-assistance in a crisis, they are far less troubling for IMF implementation of an odious regime policy, due to its much narrower scope. Rather than applying to every member country, as ex ante conditionalities would, the odious regime policy would be limited to extreme cases. That is, the policy would be enforced only against odious regimes, a hopefully rare occurrence.

46. INTERNATIONAL FINANCIAL INSTITUTIONS ADVISORY COMMISSION, REPORT OF THE INTERNATIONAL FINANCIAL INSTITUTIONS ADVISORY COMMISSION (2000), available at http://www.house.gov/jec/imf/meltzer.pdf.

47. See Charles Calomiris, The IMF's Imprudent Role as Lender of Last Resort, 17 CATO J. 275-94 (1998); Olivier Jeanne \& Jeromin Zettelmeyer, International Bailouts, Moral Hazard and Conditionality, 16 ECON. POL'Y 409, 409-32 (2001); Raghuram G. Rajan, Institutional Reform and Sovereign Debt Crises, 25 CATO J. 17-24 (2005); Jonathan D. Ostry \& Jeromin Zettelmeyer, Strengthening IMF Crisis Prevention (IMF Working Paper WP/05/206, 2005), available at http://www.imf.org/external/pubs/ft/wp/2005/wp05206.pdf.

48. See Ostry \& Zettelmeyer, supra note 47. 
In addition, unlike with benign but financially precarious regimes, precipitating a financial crisis for an odious regime would be-modulo the humanitarian concerns discussed earlier-only for the better. Odious regimes tend to arise when there are civil wars or other forms of conflict between polarized factions. Such conflicts are clearly welfare-reducing for the countries in which they take place, and their incidence may be reduced if the cost of conflict can be raised for all belligerents. Unfortunately, the rapid growth in the international arms trade in the past fifty years has sharply reduced the costs of wars. From this perspective, an odious regime policy would have the countervailing effect of raising the financial costs of conflict, as any victorious odious regime would not be able to borrow in international financial markets. If a plundering government is either forced to stop its pillage or forced out of power because of a financial crisis triggered by the IMF's condemnation of the odious predatory regime, the crisis would actually be welfare-improving.

It is interesting that most discussions on ex ante conditionality are framed as an agency problem, where the principal (the IMF) is to provide insurance against crises to agents (the member countries) without undermining incentives for financial prudence. The odious regime problem is of a different nature. An odious regime no longer honors the fundamental "social contract" principles that underlie international financial cooperation. As such, the international community is relieved of its obligation to provide insurance against crises for such regimes and should intervene only to mitigate the financial crisis faced by an odious regime as a way of forestalling a humanitarian crisis, or to avoid a systemic contagion.

\section{VI \\ CONCLUSION}

This article has made two main contributions to the odious debt debate. First, it states a case for shifting from debt-by-debt approaches to a policy that seeks to identify odious regimes. Because the literature seems to lack a welldeveloped definition of odious regime, a new definition is offered here: a regime is odious if it engages either in systematic suppression or in systematic plundering. This definition is intentionally narrow; odious regime policy should be limited to regimes that are truly odious, whose borrowing is indefensible on both moral and economic grounds.

Second, the article provides a roadmap for implementing this definition of odious debt. The proposal set forth here could be implemented by existing decisionmakers employing their existing expertise. The U.N. Security Council would identify regimes that are characterized by systematic suppression. A conclusion by the Security Council that a regime is odious could be made either while the regime was in place or thereafter, and would nullify the obligations incurred by the regime. The IMF would attach the odious label to regimes it found to have engaged in systematic plundering. Additionally, the IMF would 
deny liquidity assistance and the enforcement of any debts incurred by a regime it identified as odious.

It may be that odious regimes will always be with us. But we believe an odious regime policy could curb some odious regimes, and perhaps prevent others, by giving the international community a new tool for taking a stand against unconscionable regimes. 